\title{
EIGHTEENTH-CENTURY HEALTH AND SOCIAL SERVICE IN THE POTTERY INDUSTRY OF NORTH STAFFORDSHIRE
}

by

\author{
E. POSNER*
}

\begin{abstract}
Few Social Contrivances ... have a better claim to approbation and support that those simple establishments, called 'benefit clubs' whose object is to exemplify one of the wisest political maxims 'That by association of the many, Few will be assisted.' (Sir Frederick Morton Eden, 1797).
\end{abstract}

PotTERY MANUfaCtURE became the staple industry of North Staffordshire at the end of the seventeenth century. At that time it produced coarse mottled and mostly salt-glazed jugs, butter pots and similar domestic articles together with a very limited output of 'ornamental ware' (Plot 1686, Thomas 1971).

The main occupational risk in those days was from lead poisoning, caused by painting vessels with 'smithum' (Plot 1686) a process which in the 1750s gave way to 'dipping' the fired ware in fluid glazes containing either soluble lead oxide or lead carbonates (Meiklejohn 1963a). In 1720 Thomas Astbury brought the Dannean present of finely ground and calcined flint to the Potteries thus adding silicosis to the specific hazards of the potter (Shaw 1829, Meiklejohn 1969). As early as 1726 Thomas Benson, a local engineer, supported his application for the wet grinding of flint by saying '.. any person ever so healthful or strong working in this business'-meaning the dry crushing and grinding of flint-'cannot possibly survive above two years, occasioned by the dust sucked into his body ...' (Meiklejohn 1963b).

The risk from plumbism in pottery manufacture has been gradually, but not entirely, eliminated over the past 300 years by the introduction of leadless or lowsolubility glazes (Hamilton 1953-1970, Knappett 1969), the hazard from silicacontaining dusts-albeit in a much diminished degree-has remained with us until today (Department of Health and Social Security 1944-1970, Department of Employment 1971, Posner 1969).

The long and painful history of nineteenth- and twentieth-century factory legislation for the British Ceramic Industry has been amply documented in numerous official reports and comprehensively summarized by Meiklejohn in his Milroy lectures (1963a and $b$ ). The very early measures taken by some manufacturers and the self-help by their workmen in the eighteenth century has so far attracted little attention.

The transformation of the peasant and cottage type of pottery production to the conditions and demands of the Industrial Revolution is inseparable from the names of Josiah Wedgwood Sr. (1730-1795) and his partner Thomas Bentley (1730-1780), a

* Central Outpatients Department, Hartshill, Stoke-on-Trent.

Medical History, 1974, vol. 18. 
Eighteenth-century Health and Social Service in the Pottery Industry of N. Staffs.

merchant enterpreneur whom McKendrick (1964) rightly called Wedgwood's 'alter ego'. They introduced new materials, used mechanical power, built larger factories for both 'useful' and 'ornamental' ware and invaded the foreign markets. The fact that the consumption of tea in Britain rose from $1,500,000 \mathrm{lb}$. to $6,000,000 \mathrm{lb}$. during Wedgwood's lifetime must have considerably contributed to his enormous success (MacPherson 1805). The industry employed only about 500 men, women and children in 1750, a number which had escalated to more than 15,000 at the time of Wedgwood's death (Thomas 1971).

Unlike most other English manufacturers of his time, but probably influenced by the example of his friend and fellow-member of Birmingham's Lunar Society, Matthew Boulton (1728-1829), Wedgwood and Bentley established some medical provisions for their workmen at Etruria (Mantoux 1968, Posner 1971). For this private health scheme they engaged the services of a Newcastle-under-Lyme apothecary, James Bent (c. 1740-1812), who was assisted by his younger brother William Bent (1742-1820), another apothecary Bagnall-Beech, and later by a 'man-midwife' John Crewe (Bemrose, 1972).

According to his one and only published paper (Bent 1774) 'redde' by Dr. William Hunter (1713-1783) to the Royal Society, Bent must have been a most accomplished surgeon, and one of the first who successfully performed the conservative operation of excising a tuberculous head of the humerus instead of the mutilating procedure of amputating the whole arm at the shoulder joint (Posner 1971). He also amputated in 1768 Josiah Wedgwood's osteomyelitic right leg, an affliction caused by what Wedgwood's main biographer, Eliza Metyard, called 'an eminent violent and confluent smallpox'. Despite the absence of asepsis and anaesthetics, the operation was a remarkable success leaving Wedgwood with little disability.

Some of the accounts and receipts for Wedgwood's health scheme submitted by Bent have been found at the Wedgwood Museum in Barlaston (Barlaston documents 2393-31). The annual expenditure ranged from $£ 100$ to $£ 120$, and the items of service -only a few of which can be quoted here-are characteristic for the polypharmacy of the eighteenth century:

$\begin{array}{lr}\text { Two ozs of Liquorice powder } & 6 d . \\ \text { Glauber salts } & 2 d . \\ \text { Turkey rhubarb } & 4 d . \\ \text { Two ozs of Jalop } & 3 / 1 d . \\ \text { Two ozs of Buckthorne syrup } & 8 d . \\ \text { Chamomile flowers } & 1 /-d .\end{array}$

Bent invariably charged $5 s$. for a domiciliary visit, but a bleeding of his workmen reduced Wedgwood's growing fortunes by only one shilling. Strangely enough 'the bark', one of the few effective drugs of that time, does not figure in Bent's accounts.

At the time of Josiah Wedgwood's death in 1795, friendly societies and 'clubs' had mushroomed all over the United Kingdom. Their origin was closely associated with the self-help of Huguenot refugees who had no claim upon the Poor-rates (Smiles 1869). By 1793 their membership was estimated between 700,000 and 800,000 (Eden 1801, Thompson 1965, Poynter 1969). Their developments and vicissitudes have been well described by Sir Frederick Morton Eden (1766-1801) in his monumental work 


\section{E. Posner}

The State of the Poor (1797), and in more recent times by Gosden (1961), Roberts (1961), Thompson (1965), Poynter (1969) and Inglis (1971), amongst many others.

The Reverend John Acland's plan (1768) to change the existing poor laws into what amounted to a national insurance scheme, had come to nothing, but the Friendly Societies Act of 1793 had made the societies and clubs respectable, although in later years many of them-rightly or wrongly-were accused and persecuted for providing cover of seditious activies and circumvention of Pitt's Combination Acts of 1798 and 1799 (Thompson 1965).

The Potteries were late in founding friendly societies mostly because they remained one of the most isolated growing points of the Industrial Revolution until Wedgwood, ably helped by his friends, Bentley, Erasmus Darwin (1731-1802), and the brilliant engineer Thomas Brindley (1716-1772) improved communications with the outside world by turnpikes and canals (Metyard 1855-1856, Ward 1843, Warrilow 1952, Thomas 1971).

The prevailing attitude of successive governments and manufacturers towards friendly societies has been poignantly shown by Roberts (1961): 'They saw in them a means of keeping down the Poor Rates', and in this context a letter by Wedgwood to Dr. Robert Waring Darwin, the son of Erasmus Darwin, is highly relevant and characteristic:

To Dr. Darwin, Shrewsbury.

Etruria Feb.7.1793.

Dear Doctor,

My son Jos has transmitted to me from London a letter of yours to him containing some queries respecting the influence of regulations among our workmen upon the parish rates. This, my Dear Sir, is a subject which it can do no good, and may do much harm, to bring publicly forward at all, for the most distant suggestion among workmen that they are investing their money to save the parish may do irreparable mischief. Some of the advantages and manufactures in a town and its vicinity are the great increase which they occasion in the rent of land and houses; the employing of the idle and keeping them out of mischief, and the increased consumption of all kinds of produce, an increase far more than sufficient to counterbalance any that can be supposed to take place in the poor rates. Though the regulations which workmen establish among themselves do certainly contribute much to lessen the parish rates by supporting in sickness and in old age those who otherwise fall upon the parish, yet if the good effect of the Friendly Societies or Clubs was publicly urged as a motive for encouraging them, or as an instance of their utility, I fear it would be much more likely to retard than promote them. A few years ago, a bill was brought into Parliament and printed for encouraging and promoting these societies. Some of the leading members did me the honour of consulting me on the subject, and desired me to give them my thoughts in writing upon the bill, which I did, and I shall now enclose you a copy so far as relates to this subject. The bill was rejected, and has not since passed in any form. Our Friendly Societies are the simplest things imaginable, a workman pays $2 d$. or $3 d$. per week, and receives 3 or 4 shillings per week when sick, and a less sum when superannuated. I heartily wish you success in your laudable endeavours to serve your town and neighbourhood, and am

Dear Doctor Your sincere and affectionate friend and humble servant, Jos. Wedgwood.

In other words, and typical of the practical Josiah Wedgwood: the friendly societies are a very good thing, but let us be quiet about them.

In mentioning 'Our friendly societies' the Hanley New Friendly Society founded 'in the 28th year of the Reign of King George the Third over Great Britain etc. and in the year of our Lord 1788' must have been first and foremost in Wedgwood's mind. 
Eighteenth-century Health and Social Service in the Pottery Industry of N. Staffs.

One year after his death its 'Articles of Agreement' (Keele document 2620-4) were copied almost verbatim and incorporated into those of the Original Etruria Friendly Society, albeit with some important exceptions.

The timing of the inception of the Etruria Society is significant. Josiah Wedgwood Sr. had virtually lived above his shop-in Etruria Hall overlooking his new manufactories of useful and ornamental ware which he ruled with a strong and paternalistic hand. After his death, 'Etruria Hall was deserted, left empty and desolate. The Wedgwoods did not cease to take an interest in their workmen though their kindly efforts came through the hands of a middle person, and things did not thrive so well' (Wedgwood, H. A. 1970). Josiah's son and heir, Josiah Wedgwood Jr., moved to the splendid mansion of Meir (Staffs), became Charles Darwin's father-in-law, but took considerably less interest in the affairs of his business and workpeople than his father. His name is conspicuously absent from the list of High Stewards and Officers of the newly formed Etruria Friendly Society.

In contrast to the sober preamble to the rules of the Hanley New Friendly Society, which simply states as its aim 'the Assistance of all and every such member or members as may be rendered incapable of business, and also to promote Sobriety and Industry ...' the articles of the Etruria Society open with splendid oratory (Fig. 1).

The rules for the society's four weekly meetings reflect Eden's (1797) stern warnings: 'Friendly Societies are not to degenerate into debating Clubs, and . . . convivial meetings on a Saturday night become the aptest vehicles for disseminating principles subversive of subordination and submission to the Law of the country. The money spent on a club night is entirely lost to a labouring family.'

However, Sir Frederick was also a man of great common sense with insight into the human condition: 'these societies do not aim at perfection but improvement. If they cannot correct the inclination (which is too often caused by hard labour) for conviviality and dissipation, they do at least convert a vicious propensity into a useful instrument of economy and industry to their members ... subsistence during sickness and independence in old age.' The vicious propensity for the members of the Etruria Friendly Society consisted of an allowance of two pence 'in liquor' at the monthly meetings.

The strict rules of morality, procedure and institutional etiquette of early friendly societies have been summarized by Thompson (1965) and articles V and VI of the rules of the Etruria Friendly Society comprehensively cover any felonies or misdemeanors likely to be committed at its meetings. During the reign of George III it is a piquant but perhaps characteristic fact that 'any treasonable expression used' involved a fine of two pence, the same amount as for cursing, gaming or refusing to be silent, but considerably less than the penalty of six pence for arriving at the meeting 'disguised in liquor', keeping one's hat on or striking a fellow member.

\section{ELIGIBILITY FOR MEMBERSHIP}

On joining, members had to be between the ages of fifteen and thirty years, and had to prove that they were not 'lame or infirm'. Married men had to certify to the High Steward that their wives were of 'a sound constitution'. Although the methods of inoculation against smallpox introduced into England by Lady Wortley Montagu in 


\section{E. Posner}

1721 were widely used in the Potteries by the better endowed-including the Wedgwood family (Barlaston documents E. 18139-25)-a survival from an attack of smallpox was a conditio sine qua non for joining the society.

The most significant primary exclusion from membership simply reads: 'No person shall be admitted a member of this society who is a miner or that follows glossing'. Quite obviously the high morbidity and mortality from lead poisoning resulting from 'glossing' which is the glazing of the fired ware (Fig. 2), and the accidents and respiratory disease of the North Staffordshire coal miners would have overtaxed the society's resources.

Imprisonment for felony, fraud, burglary or murder led to immediate expulsion, but incarcerated debtors were allowed to retain their membership provided they were able to continue paying their contributions. Volunteers for His Majesty's services by land, sea, militia or merchant ship automatically lost their membership but those 'ballotted' to serve in the militia retained some benefits whether they joined up or not. Those who were 'impressed' in His Majesty's services and being maimed or rendered incapable of getting their living were entitled to receive benefits, as did other members provided they left a wife or other persons to pay their dues under the articles. Any member 'pricked down' to serve in the militia and joined up knowing that he had no right to serve by virtue of being too young or too old, too infirm or having too many children, forfeited all benefits from the society.

Contributions of eight pence 'to the stock' had to be paid by each member of the society at the four weekly meetings, whether he 'was present or absent'. As Weatherill (1971) has shown, the weekly wages of the most highly skilled craftsmen in the pottery industry at that time were about ten shillings a week. Their contributions were therefore in the region of 7 per cent of their income, provided they did not have to pay fines for the above quoted offences. The respective proportion for unskilled labourers who earned only about $6 s$. a week, would have been considerably higher (about 11 per cent) but it is unlikely that many of them were fully paid-up members. The stocks of the society were augmented by fining its officers for not attending meetings and members for failing to pay off their arrears.

Documents now deposited at Keele University suggest that in later years Messrs. Josiah Wedgwood \& Sons made considerable contributions to the society's fund. In 1827 for instance the sum of $£ 170$ with interest (Keele documents 2622-4, 2624-4, 2625-4).

Sickness Benefits: Article $X$ states: ' $\ldots$ if any member who has been in this society the space of one year, shall by sickness, lameness or any other calamity with which it shall God please to inflict him be rendered incapable of working for his support ... he shall receive five shillings a week out of the stock until he shall be able to follow his business'. As this was about half of the normal earnings of a highly skilled workersuch as a potter's thrower or turner-it must be considered a generous benefit. However, after six months' incapacity, benefits were reduced to $3 s .6 d$. per week, and after recovery there had to be an interval of six months before another claim could be considered. Venereal disease* or injuries received by fighting 'unless he can prove he was

*In merely mentioning 'venereal disease' the Etruria potters showed a more genteel disposition than the Watermen of Newcastle-upon-Tyne (1804) who referred to the same delicate matter with 'any illness got by lying with an unclean woman, or is clap't or pox'd.' 


\section{Eighteenth-century Health and Social Service in the Pottery Industry of N. Staffs.}

standing in his own defence and did not begin the quarrel' were not considered calamities which attracted benefits. On the other hand if any member, through age or other infirmity should be past labour he shall receive the sum of three shillings and six pence weekly . . . during life', a provision which does not compare unfavourably with present-day extant or intended pension schemes. All benefit claims had to be certified by the Minister or Curate of the respective parishes and the society employed physicians, surgeons and apothecaries to prevent 'counterfeiting, sickness, lameness or other calamities', a felony which led to immediate expulsion of the culprit.

In contrast to the articles of the Hanley Society which according to Article VII employed a surgeon "who shall be paid the sum of thirteen pounds yearly $\dagger \ldots$ in consideration whereof he shall regularly visit, attend upon and take care of each and every member . . . in all cases of surgery, and also find and provide sufficient physic for them' (Keele document 2620-4), the articles of the Original Etruria Society do not refer to medical care.

Death and funeral benefits: a widow-provided she was the deceased's first wifewas allowed ten pounds towards the expense of the funeral of her husband in case the society's fund not too small', a most generous amount, but then as now funerals in the Potteries were elaborate and costly affairs and a pauper's funeral 'the ultimate social disgrace' (Thompson 1965). The death of a wife-but only of the first one-resulted in five pounds' benefit to the widower.

Fringe benefits: the High Steward was obliged by Article XII to 'cause a sermon to be preached in some neighbouring church, one every Stoke Wakes Tuesday'-the only traditional holiday for potters at that time. Every member 'if in health' and living within a radius of three miles from Etruria had to attend at nine o'clock that morning at a place appointed by the steward to receive a card entitling him to a dinner and a 'society stick'. He had to earn his dinner by walking with his stick to the church, and from thence to the place appointed to dine in decent, sober, orderly and regular profession'. This great annual event had its inherent hazards; attempts for partaking in the dinner without marching to it in procession resulted in fines on the spot of sixpence, and bad manners, such as entering the dining hall before the High Steward, minister or other officers, were punished by 'forfeit of one shilling to the stock' or by exclusion from the repast.

Wakes Tuesday was also election day for the Society's officers for whom the 'old victualler' had to lay on a 'sufficient dinner' at eight pence a person, each of whom was obliged to spend another four pence in ale.

The Articles of the Original Etruria Friendly Society mirror the harsh but colourful life in the Potteries of the late eighteenth century. It is of some interest to compare them with those of the society's successor, the Sick and Divident Society in Connection with Messrs. Wedgwood's Manufactory, Etruria, seventy years later (Keele document 2625-4). These are devoid of oratory, but in material terms only a little progress had been made. Monthly contributions had risen by four pence to one shilling and were deducted at source, and sickness benefits had been increased by one shilling only. Members were entitled to benefits after only twelve weeks' membership (instead of

IIn the above named document thirteen pounds has been crossed out and substituted in ink by 'he agrees for'. 


\section{E. Posner}

twelve months), but contributions towards funeral expenses had been considerably reduced to three pounds. Intoxication and riotous conduct still led to disqualification from benefits and/or expulsion.

The changed climate of morality is reflected in the omission of specifically mentioning venereal disease, but it must be assumed that these were hidden in 'any disorderly way of living, bringing disorder, lameness, sickness or infirmity' which remained a barrier to any benefits. On the other hand-one is glad to notice-those who needed it most, the lead-exposed workers, miners, and ex-miners, were not any more disqualified from joining the society.

There can be little doubt that the pottery population of the eighteenth century benefited from Josiah Wedgwood's philantropic scheme and their own self-help. On the other hand one must take notice how J. T. Arlidge (1822-1899), the great pioneer of industrial health in North Staffordshire, evaluated friendly societies: 'To a certain extent the members are a select body, representing the more steady and prudent of the number and containing a certain proportion of individuals who are not in actual work as artisans, and escape, more or less, the disadvantage to health connected with employment. The consequence is that the returns convey a more roseate view of its vital statistics than positively belongs to the occupation' (Arlidge 1892).

\section{ACKNOWLEDGEMENTS}

I am most grateful to Messrs. Wedgwood \& Sons, Barlaston, and to the Librarian of the University of Keele, who allowed me to use and reproduce documents in their possession. Mr. I. H. C. Frazer, Archivist at Keele University, Mr. W. A. Billington, Curator of the Wedgwood Museum, Mr. E. Cornelius, Librarian of the Royal College of Surgeons, and Mr. P. Bemrose of the Newcastleunder-Lyme Museum, greatly helped me in preparing this paper. Mr. D. H. Roper, Secretary of the National Conference of Friendly Societies, drew my attention to most useful references. I also thank Mrs. H. Venables for secretarial help.

\section{REFERENCES}

AClAND, J., A Plan for Rendering the Poor Independent of Public Contributions. Founded on the basis of Friendly Societies, London, 1768.

ArLidge, J. T., The Hygiene, Diseases and Mortality of Occupations, London, 1892.

Articles of the Friendly Societies of Watermen (Newcastle 1804). Quoted from Thompson 1965.

Barlaston Documents 2393-31, and E. 18139-25.

BEMrose, P., personal communication, 1972.

Benson, Thomas, application for patent, 1726. Quoted by Meiklejohn (1969).

BENT, J., 'Account of a woman enjoying the use of her right arm after the head of the os. humeri was cut away', Phil. Trans. R. Soc. Lond., 1774, 64, pt. II, 353-56.

Department of Health \& Social Security (Previously Ministry of Pensions) Annual Reports, London, H.M.S.O., 1944-1970.

Department of Employment, Pattern of Progress, Second Report of Joint Standing Committee for the Pottery Industry, London, H.M.S.O., 1971.

Eden, SIR Frederick M., The State of the Poor or an History of the Labouring Classes in England, London, 1797.

EDEN, SIR Frederick M., Observations on Friendly Societies, London, 1801.

GosDen, P. H. J. H., The Friendly Societies of England, Manchester, 1961.

Hammton, J. S., Annual Reports, Public Health Department, Stoke-on-Trent, 1953-1970.

IngLIs, B., Poverty and the Industrial Revolution, London, 1971. 


\section{PREFACE.}

AN is furmed a social bcing; the sorereign 1 ruler of the reorld has been pleased to place us in this life as depentants upon cach other, and in contimual need of mutual assistance and support, and has interwoven in our conslifutions those humane and sympathetic affections sohich roe alzonys feel at the distress of our fellow crentures. How greatly is a beneficent and generous spirit rewoarded in contributing to relieve that distress! Of all the delights which human nature is capable of enjoying, the most lively and transporting are those which foro from sympathy and passion, as they are not only the must pleasing in their immediate exercises, but also in contemplation and refection. Every bemevolent mind thercfore twho sincerely delights in the good of others, will not fail to improve cvery opportunity to pronote the hajpiness and comfort of those, in particular, who are afticted zouth sickness, lameness, blindness, or any such calamily, by which they are deprived of the mieans and power of sup. porting (not only theniselves, but perhaps) a numerous family. Thiat this is the true and laudable intcution of this Society, the following articles ruilt sufficiently explain, zohere exery disorder with withich any of its members may be afflicted, is, as far as is consistent with the general good of this Socicty, so relieved as at least to prevent want from coming within his doors.

Figure 1.

Preface to the Articles of the Etruria Friendly Society. 


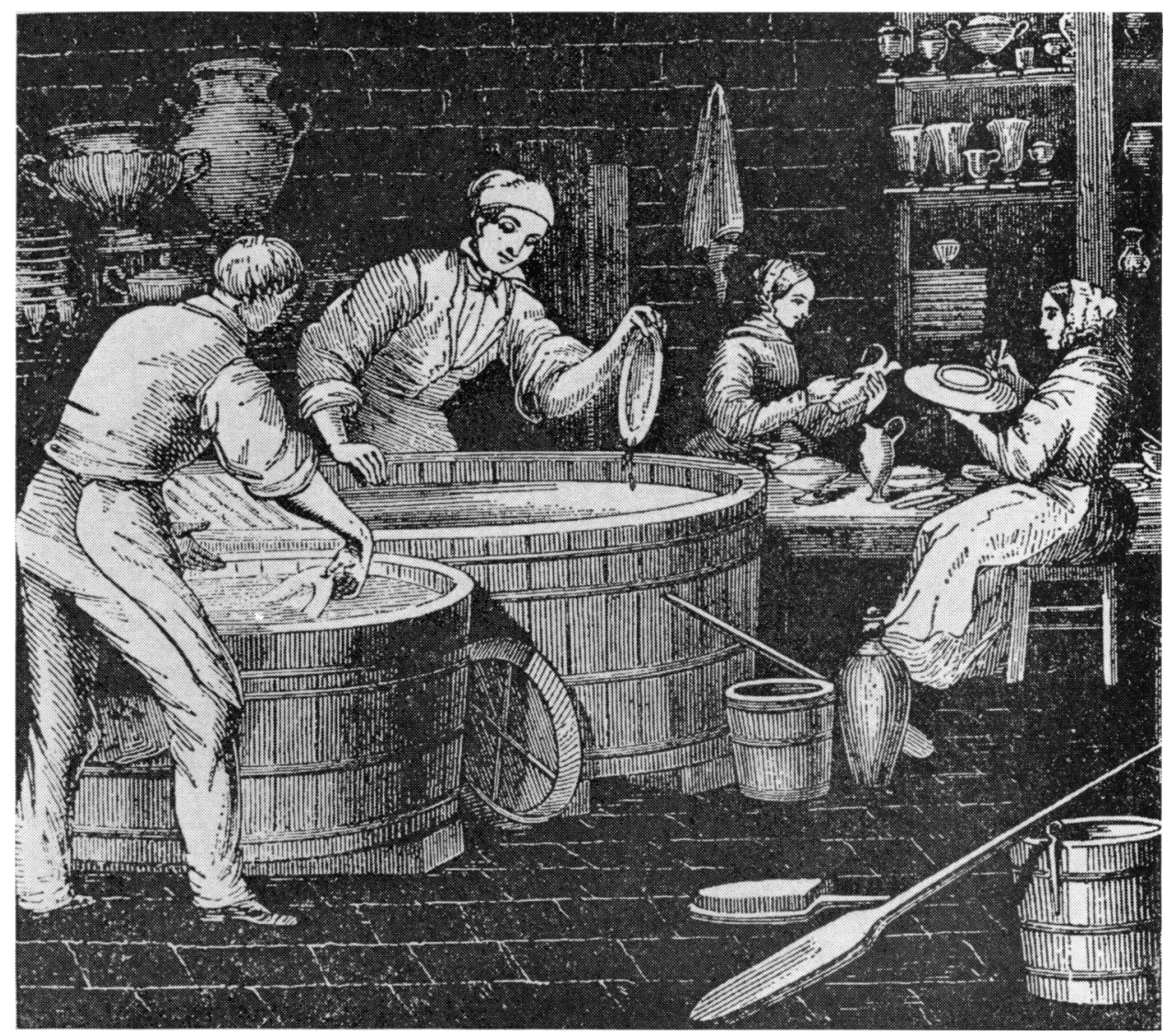

Figure 2.

Glaze Dippers.

(By courtesy of the Curator of the Museum of the North Staffordshire Medical Institute, Stoke-on-Trent.) 
Eighteenth-century Health and Social Service in the Pottery Industry of N. Staffs.

Keele Documents: $2622-4,2624-4,2625-4,2620-4$.

KNaPpett, C., 'Lead Poisoning', in Health Conditions in the Ceramic Industry, ed. C. N. Davies, Oxford, 1969.

MacPherson, Annals of Commerce, Manufactures, Fisheries and Navigation, London, 1805.

Mantoux, P., The Industrial Revolution in the Eighteenth Century, New York, 1968.

McKendrick, N., 'Josiah Wedgwood and Thomas Bentley', Trans. R. Hist. Soc., 1964, $14,1,33$.

Meiklejohn, A., 'The successful prevention of lead poisoning in the glazing of earthenware in the North Staffordshire Potteries', Br. J. indus. Med., 1963a, 20, 169.

MeiklejoHN, A., 'The successful prevention of silicosis among China biscuit workers in the North Staffordshire Pottery industry', Br. J. indus. Med., 1963b, 20, 255.

MeIKeljohn, A., 'The History of Occupational Respiratory Disease in the North Staffordshire Pottery Industry', in Health Conditions in the Ceramic Industry, ed. C. N. Davies, Oxford, Pergamon, 1969.

METYARD, E., The Life of Josiah Wedgwood, London, 1855-56.

The Original Etruria Friendly Society Articles, 1796, Keele Documents, 2621-4.

PLot, R., Topographical Study of Staffordshire, 1686.

POSNER, E., 'Pneumoconiosis in the North Staffordshire Pottery industry', in Health Conditions in the Ceramic Industry, ed. C. N. Davies, Oxford, Pergamon, 1969.

Posner, E., 'James Bent, Josiah Wedgwood and Mary Turner', North Staff. med. Inst. J., $1971,4,8-12$.

PoYnter, J. R., Society and Pauperism. English Ideas on Poor Relief, London, 1969.

ROBERTS, F., 'The Influence of Health Insurance Schemes', in Evolution of Medical Practice in Britain, ed. F. N. L. Poynter, London, 1961.

Rules and Regulations of the Sick and Dividend Society in Connection with Messrs. Wedgwoods Manufactury. Etruria (1868), Keele Documents 2625A-4.

SHAw, S., History of the Staffordshire Potteries, Hanley, 1829.

SMILES, S., The Huguenots, London, 1869.

Thomas, J., The Rise of the Staffordshire Potteries, Bath, 1971.

ThOMPSON, E. P., The Making of the English Working Class, London, 1965.

WARD, J., History of the Borough of Stoke-on-Trent, London, 1843.

WARRILOW, E. J. F., History of Etruria 1760-1951, Hanley, 1952.

WeAtHerill, L., The Potiery Trade and North Staffordshire 1660-1760, Manchester, 1971.

Wedgwood, H. A., 'Alfred Bourne and Early Wesleyanism at Etruria', in People of the Potteries, ed. J. Thomas, Bath, 1970.

WeDgwood, J., letter to R. W. Darwin, 1793. Quoted from Finer, A., and Savage, C. The Selected letters of Josiah Wedgwood, 1965, p. 338. 